\title{
VARIETY OF VITAMIN D RECEPTOR (VDR) GENE POLYMORPHISMS AND SERUM LEVELS OF VITAMIN D IN PATIENTS WITH TYPE 1 DIABETES
}

\author{
1Y.V. Dydyshko, ${ }^{1}$ A.P. Shepelkevich 1, ${ }^{2}$ N.A. Vasilieva, V.V. Zhukouskaya ${ }^{1,3}$ \\ Belarusian state medical university ${ }^{1}$, \\ Republic center of medical rehabilitation², Minsk, Belarus \\ Department of Clinical Science and Community Health, Milan, Italy ${ }^{3}$
}

\section{BACKGSIOUND AND AJJلJ}

Currently relationship between the decrease in vitamin $D$ (VD) levels and the formation of bone pathology has established. The presence of certain vitamin D receptor (VDR) polymorphisms has been suggested to be associated with the serum vitamin D. Therefore, the aim of study was to assess the association between VDR single nucleotide polymorphisms (SNPs) in type 1 diabetic patients and serum VD.

SUBJECJS AND JリEJ'JODSد

\section{T1D patients (28 men and 38 women)}

Data are expressed as mean \pm SD

$$
\begin{gathered}
31,23 \pm 8,41 \\
13,40+7,41 \\
69,25+11,59 \\
170,67+8,69 \\
23,4+3,15 \\
80,74+9,5 \\
17,82 \pm 7,95 \\
8,25+0,95
\end{gathered}
$$

RंESUL「S

There was a substantial decrease in serum levels of VD in type 1 diabetic (TID) patients compared with the control $(48,66 \pm 6,13$ vs. $123,47 \pm 15,49 \mathrm{nmol} / \mathrm{l}, \mathrm{p}<0.001)$.

There were significant differences in the levels of VD in patients with VDRApal SNPs: wild homozygotes $37,5 \pm 8,12$, in heterozygotes $44,2 \pm 12,35$, in mutant homozygotes $71,29 \pm 16,36 \mathrm{nmol} / \mathrm{l}, \mathrm{p}<0.001$. Similar data were obtained among carriers individuals with VDR-Fokl SNPs $(27,32 \pm 4,89$ vs. $53,135 \pm 4,67$ vs. $\quad 58,2 \pm 7,7 \quad \mathrm{nmol} / \mathrm{l}$, $p<0,001)$.

CONCLUSIONS:

\section{The research involved:}

Anthropometry of patients

General clinic examination

Biochemical analysis:

Cerum Vitamin D

HBA1

Ca total, $\mathrm{Ca}++, \mathrm{P}$

C-terminal telopeptide (CTX)

VDR genotyping analysis (VDR-FOKI - Fokl (BseGI), VDR-Apal - Apal)
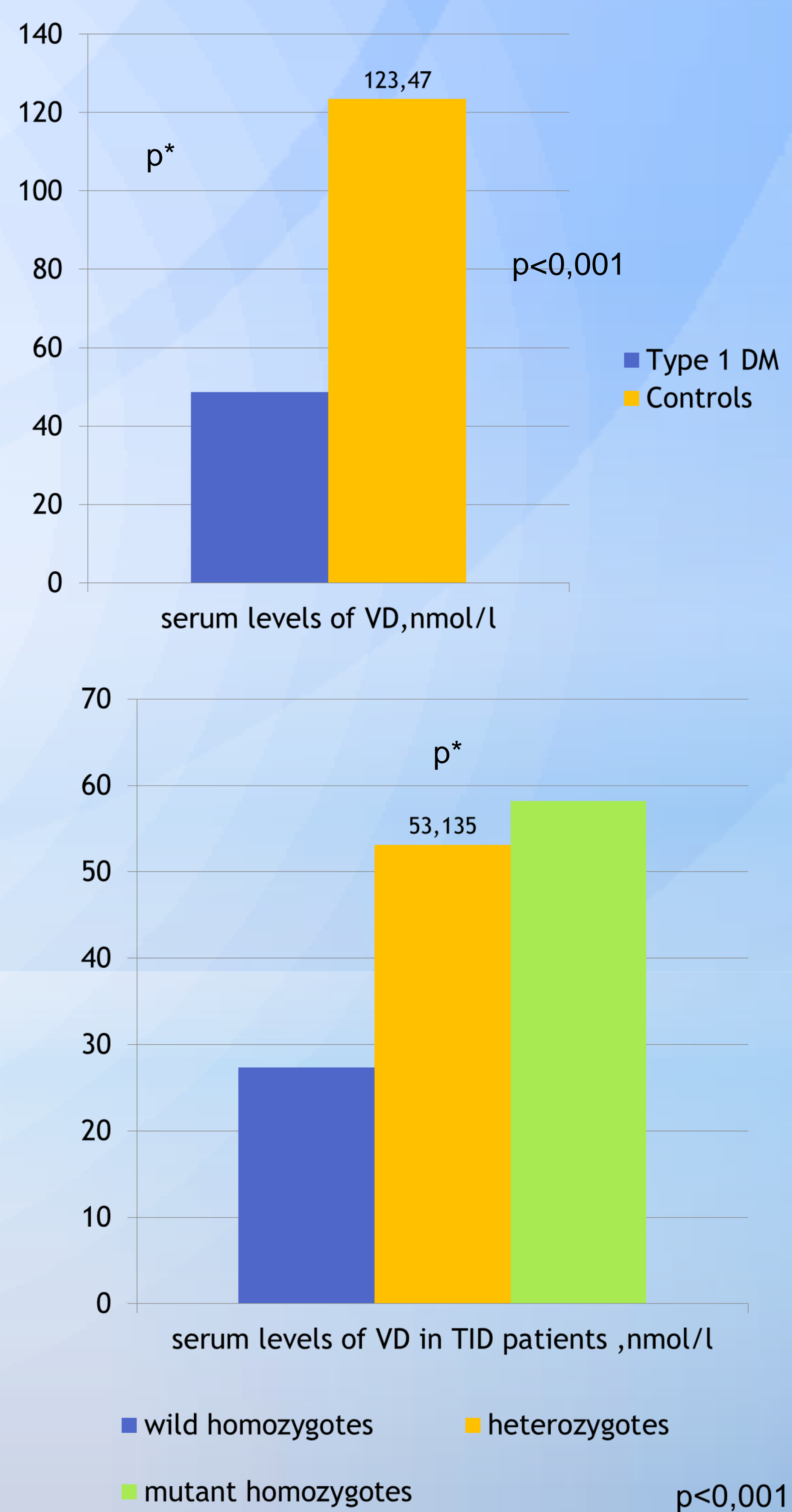

patients with VDR-FokI SNPs

patients with VDR- Apal SNPs

The results of the study reflect a significant decrease serum VD in patients with type 1 diabetes and VDR gene polymorphism's influence on these processes to need further study 